\title{
Cunhal não foi Carrilo? Estratégia e Táctica do Partido Co- MUNISTA PORTUGUÊS DURANTE A CRISE REVOLUCIONÁRIA DE 1975
}

\section{RAQUEL CARDEIRA VARELA}

Universidade Nova de Lisboa

RESUMO: Vários autores têm acentuado a divergência política entre a estratégia do Partido Comunista Português na Revolução dos Cravos em Portugal (1974-75) e a política 'eurocomunista' seguida pelo Partido Comunista de Espanha. Este artigo, realizado a partir de fontes primárias nacionais e internacionais, traça a história da política do PCP durante o «Verão Quente» de 1975. Focar-nos-emos na relação histórica do partido com os movimentos sociais, por um lado, e, por outro, na sua relação com o Governo. Finalmente, compara-se a política do PCP liderado por Álvaro Cunhal e a política do PCE dirigido por Santiago Carrillo, acentuando as semelhanças — defesa da coexistência pacífica, acordo com os partidos socialistas ibéricos, influência nos principais sindicatos-e as diferenças, que na nossa óptica se centram sobretudo na defesa de uma ordem capitalista fortemente regulada por parte do PCP, com a concretização de uma reforma agrária e um processo de nacionalizações de um sector importante da economia, por oposição à aceitação dos Pactos da Moncloa por parte do $P C E$, que assumem uma forma de economia de mercado de cunho mais liberal. Finalmente, a questão do regime (republicano ou monárquico) distingue também a política dos dois partidos.

\section{Palavras-Chave: Partido Comunista Português. Revolução dos Cra- vos. Partido Comunista Espanhol. Movimentos So- ciais.}

Raquel Cardeira Varela es investigadora es Instituto de História Contemporânea da Faculdade de Ciências Sociais e Humanas da Universidade Nova de Lisboa. Dirección para correspondencia: Av. de Berna 26-C 1069-061 Lisboa Portuga. Correo electrónico: raquel_cardeira_varela@yahoo.co.uk. 


\title{
Cunhal Was not Carrillo? Stratigies and Tacticts of the Portuguese COMMUNIST PARTY DURING THE REVULUTIONARY CRISIS OF 1975
}

\begin{abstract}
Several authors have highlighted the divergence between the political strategy of the Portuguese Communist Party in the Carnation Revolution in Portugal (1974-75) and the 'Eurocommunist' politics carried out by the Communist Party of Spain (PCE). This article, based on national and international primary sources, traces the history of PCP politics during the «Hot Summer» of 1975. We focus on the party's historic relationship with social movements, on the one hand, and secondly on its relationship with the Government. Finally, we compare the politics of the PCP, led by Álvaro Cunhal, with the politics of the PCE, led by Santiago Carrillo, highlighting the similarities - the defence of peaceful coexistence, the agreements with the Iberian socialist parties, their influence on major trade unions - and the differences, which, in our opinion, are mainly centered around the PCP's defense of a strongly regulated capitalist order, including the completion of land reforms and the nationalization process of an important sector of the economy, as opposed to the acceptance of the Moncloa Pacts by the PCE, which assume a much more liberal market economy. Finally, the issue of the regime (republican or monarchical) also distinguishes the politics of both parties.
\end{abstract}

KEY WORDS: Portuguese Communist Party. Carnation Revolution. History of the revolutions. Social conflict.

\section{INTRODUÇÃO}

Vários autores analisaram a política do Partido Comunista Português (PCP), concluindo que a contrario do Partido Comunista de Espanha (PCE), o PCP procurou em 1974-1975 fazer um 'golpe de Praga' ao estilo de 1948, tentando uma via putschista para alcançar o poder do Estado e impor um regime satélite da URSS, ligado ao Pacto de Varsóvia. Destacam-se, nesta análise, entre outros, Boaventura Sousa Santos, que defende que o PCP teve aquilo que designa como uma «vertigem insurreccional durante a crise revolucionária» ${ }^{1}$; Carlos Cunha, que defende que o PCP minimizou o parlamentarismo, depois de Abril de 1975, como forma de chegar ao poder e enfatizou outras «tácticas leninistas»²; e Carlos Gaspar, que argumenta que o PCP quis tomar o poder mas foi obrigado a recuar pela relação de forças desfavorável ${ }^{3}$. Medeiros Ferreira salienta também aquilo que considera ser a tentativa de

1 SANTOS, Boaventura Sousa, «A Crise e a Reconstituição do Estado em Portugal. 19741984», Revista Crítica de Ciências Sociais, 14 (1984), pág. 24.

2 CunHA, Carlos A., The Portuguese Communist Party's Strategy for Power 1921-1986, New York \& London, Garland Publishing, Inc., 1992, pág. 4.

3 Gaspar, Carlos, e Rato, Vasco, Rumo à memória. Crónicas da Crise Comunista, Lisboa, Quetzal Editores, 1992, pág. 33. 
controlo do aparelho de Estado e tomada de poder via extra-eleitoral, depois de Abril de 19754. Leonardo Morlino identifica um processo de «moderação» política dos partidos socialistas e comunistas do Sul da Europa, moderação esta a que teria escapado o PCP, que manteve uma «postura semileal face ao regime democrático ${ }^{5}$. Kenneth Maxwell escreve que «durante o Verão de 1975, [os comunistas] realizaram a última tentativa séria para tomar o poder na Europa Ocidental» ${ }^{6}$.

Diferentemente destas teses, alguns autores têm acentuado, dentro da complexidade que foi a história política do PCP no período revolucionário, o compromisso desta organização com o regime democrático, almejando porém uma forma de capitalismo com forte pendor regulacionista e um sector importante da economia nacionalizado. Marco Lisi salientou a tensão entre a mobilização e a negociação, que levou o PCP a parecer hesitante, mas sem evidenciar como estratégia uma transição para o socialismo ${ }^{7}$; Francisco Louçã, a partir da análise do Congresso de Alhandra de Agosto de 1975, defende que o PCP não tinha uma política de transformação global da sociedade, «no sentido de abolição das relações capitalistas de produção, que subjazem ao Estado capitalista» e que durante aquele período de tensão, de Agosto a Setembro de 1975, a luta do PCP foi pelo compromisso ${ }^{8}$; Valério Arcary sustenta que não é adequado associar a estratégia do PCP à dos bolcheviques russos: «(...) o PCP (...) aderiu aos governos provisórios, defendeu a ordem, denunciou as greves como selvagens, e o respeito à propriedade privada, promoveu campanhas de trabalho voluntário - a batalha da produção - o respeito às hierarquias, aos tratados internacionais, etc.» ${ }^{9}$.

A documentação recente, que tem vindo a ser sucessivamente desclassificada, sobretudo a nível internacional ${ }^{10}$ (como as fontes dos National Archives

4 Ferreira, António Medeiros, Portugal em Transe (1974-1985), en MAtToso, José (dir.), História de Portugal, Lisboa, Círculo de Leitores, 1993, pág. 256.

5 Morlino, Leonardo, «Political Parties and Democratic Consolidation in Southern Europe», en Gunther, R., Diamendouros P. N., (eds.), Southern Europe in Comparative Perspectiv, Baltimore and London, Johns Hopkings University Press, 1995, pág. 369.

6 MaXwell, Kenneth, A Construção da Democracia em Portugal, Lisboa, Editorial Presença, 1999, pág. 202.

7 LISI, Marco, «O PCP e o Processo de Mobilização (1974-1975)», Análise Social, 182 (2007), vol XLII, págs. 181-203.

8 LouÇã, Francisco, «A "Vertigem Insurreccional”: Teoria e Política do PCP na Viragem de Agosto de 1975», Revista Crítica de Ciências Sociais, 15/16/17 (Maio 1985), págs. 149-162.

9 ARCARY, Valério, «Uma nota histórica sobre o PCP e a revolução portuguesa: a defesa de um projecto autárquico de capitalismo regulada», Actas do I Colóquio Os Comunistas em Portugal, Lisboa, Política Operária, 2010, no prelo.

$10 \mathrm{O}$ arquivo do PCP permanece encerrado aos investigadores. Também o arquivo da URSS face a este período a Portugal está incessável. 
britânicos ou a documentação norte-americana referente à política externa dos EUA), abriu portas a uma nova onda de investigações sobre a revolução portuguesa que trouxe a este respeito novas e importantes novidades. Destacamse a este propósito duas teses de doutoramento, uma sobre a influência norteamericana em Portugal no biénio 1974-75, de Tiago Moreira de Sá11, e uma tese sobre a história da política do PCP, de Raquel Varela ${ }^{12}$. O redobrado interesse sobre a Revolução dos Cravos trouxe também na área da história da revolução dois estudos indispensáveis, que precederam aliás os anteriores. São eles a obra sobre o Conselho da Revolução de Maria Inácia Rezola ${ }^{13}$ e a história da reforma agrária durante a revolução no maior distrito do país, Beja, de Constantino Piçarra ${ }^{14}$.

A polémica sobre a política do PCP refere-se sobretudo, como assinalámos, ao período entre o Verão Quente de 1975 quando o PCP e uma frente por si dirigida, o MDP/CDE, são os únicos partidos que oficialmente apoiam o $\mathrm{V}$ Governo Provisório, um governo constituído exclusivamente por militares próximos destes partidos e/ou influenciados por alguns sectores da extremaesquerda. O debate dá-se justamente sobre este período, uma vez que todos os autores, sem excepção, admitem a participação comprometida da direcção comunista nos governos com os socialistas e os liberais do PPD, concordando que até pelo menos Março de 1975 o PCP teve uma política de contenção das reivindicações dos trabalhadores com uma forte oposição às greves e aos organismos de duplo poder, como as comissões de trabalhadores ${ }^{15}$.

Neste artigo focar-nos-emos justamente na história do PCP neste período do V Governo ${ }^{16}$, e num segundo momento procuraremos salientar, sem querer

11 SÁ, Tiago Moreira de, Os Estados Unidos da América e a Democracia Portuguesa (1974-1976), Lisboa, MNE, Instituto Diplomático, 2009.

12 Varela, Raquel, História da Política do Partido Comunista Português durante a Revolução dos Cravos (1974-1975), Tese de Doutoramento em História Política e Institucional do Período Contemporâneo, Lisboa, ISCTE-Instituto Universitário de Lisboa, Junho 2010.

13 RezolA, Maria Inácia, Os Militares na Revolução de Abril: o Conselho da Revolução e a Transição para a Democracia em Portugal, Lisboa, Campo da Comunicação, 2006.

14 PIÇARRA, Constantino, As Ocupações de Terras no Distrito de Beja. 1974-1975, Coimbra, Almedina, 2008.

15 Para uma história detalhada das comissões de trabalhadores até Fevereiro de 1975 ver PÉrez, Miguel, Contra a Exploração Capitalista. Comissões de Trabalhadores e Luta Operária na Revolução Portuguesa (1974-75), Dissertação de Mestrado em História dos Séculos XIX e XX, Faculdade de Ciências Sociais e Humanas, Universidade Nova de Lisboa, Agosto de 2008. Para a relação da história do PCP com as comissões de trabalhadores entre 25 de Abril de 1974 e 25 de Novembro de 1975 ver VArela, Raquel, História da Política do Partido Comunista Português durante a Revolução dos Cravos (1974-1975), Tese de Doutoramento em História Política e Institucional do Período Contemporâneo, Lisboa, ISCTE-Instituto Universitário de Lisboa, Junho 2010.

16 Utilizámos um amplo leque de fontes, das quais destacamos antes de mais o Avante!, jornal semanal do PCP, com uma tiragem, em alguns momentos, de centenas de milhares de 
esgotar uma história que em larga medida está em construção, algumas das diferenças e semelhanças que existem entre o PCP e o PCE durante a segunda metade da década de 70 do século XX.

\section{A RUPTURA NA COLIGAÇÃo PCP/PS/MFA}

Até Março e Abril de 1975, pese embora as diferenças substanciais que se revelaram entre o Partido Comunista Português e o Partido Socialista, quando da discussão em Janeiro de 1975 sobre a institucionalização de uma central sindical única, a Intersindical —que o PCP defendia argumentando que esta asseguraria a unidade dos trabalhadores e a que o PS se opunha defendendo o pluralismo sindical como condição da consolidação democrática do país-, a coligação governamental, com a participação crescente do Movimento das Forças Armadas (MFA) como árbitro, consegue assegurar a governabilidade do país. Porém, a partir do segundo semestre de 1975 a coligação desmembra-se, em resultado de vários factores.

Uma tentativa de golpe falhado, a 11 de Março de 1975, liderada pelo general Spínola — cujos dirigentes terão apoio político e financeiro na Espanha franquista - reflecte um processo de radicalização da revolução, caracterizada pela multiplicação dos organismos de duplo poder (nesta fase sobretudo comissões de trabalhadores e moradores ${ }^{17}$ ), pelo desenvolvimento das ocupações de terras no Sul a partir de Fevereiro de 1975, pela exigência de nacionalização da banca levada a cabo pelos trabalhadores bancários que se estende às maiores empresa do país, nomeadamente ao maior grupo empresarial, o grupo CUF.

exemplares. Neste trabalho estudámos todo o jornal Avante! entre Maio de 1974 (primeiro número legal) e Dezembro de 1975, bem como todos os documentos do Comité Central e da Comissão Executiva que estão publicados, os discursos do líder político Álvaro Cunhal e o boletim de organização do partido, $O$ Militante, cujo primeiro número legal sai em Junho de 1975. Estudámos ainda centenas de panfletos e comunicados do PCP disponíveis no Centro de Documentação 25 de Abril, o jornal UEC, da organização estudantil comunista, o Jovem Trabalhador, jornal da juventude trabalhadora do PCP. Entre as fontes destacamos também os principais documentos teóricos e programáticos do partido: Rumo à Vitória, Teses do VII Congresso e Plataforma de Emergência; Programa e Estatutos do PCP, A Revolução Portuguesa. Passado e Futuro, A Verdade e a Mentira na Revolução de Abril. A Contra-revolução Confessa-se, entre outros. Utilizámos ainda vários testemunhos e memórias, como os de José Saramago, Raimundo Narciso, Zita Seabra, Mário Soares, Vasco Gonçalves, Melo Antunes, entre muitos outros. Para a elaboração deste trabalho recorremos a diversas fontes exteriores ao PCP, como os documentos do Foreign Office do Reino Unido; os comunicados do Partido Socialista entre o 25 de Abril de 1974 e o I Governo Constitucional; a imprensa diária não partidária (República, Diário de Lisboa, Diário Popular, etc.) e o Arquivo da RTP.

17 As comissões de soldados desenvolver-se-ão a partir de Setembro de 1975. 
Como assinala o estudo de conflitos colectivos levado a cabo por Duran Muñoz, a seguir ao 11 de Março a situação social é a mais radicalizada desde o início da revolução ${ }^{18}$. Há greves, ameaças de greve e outros conflitos laborais, entre Maio e Junho de 1975, nos metalúrgicos, nos químicos, na hotelaria, nos têxteis, nas câmaras municipais, na construção civil, nas minas, electricistas, padeiros, gráficos, TAP ${ }^{19}$. As ocupações alastram pelo Ribatejo e Alentejo. As nacionalizações são levadas a cabo em dezenas de grandes empresas. E surgem as ocupações de casas, que avançam a nível nacional a um ritmo extraordinário, logo a partir de metade de mês de Fevereiro de 1975, sobretudo em Lisboa, Porto e Setúbal. As casas eram ocupadas e os moradores reuniamse, tomando decisões tão espectaculares como exigir a nacionalização da banca ou decidir que a casa vazia se tornava na creche do bairro ${ }^{20}$. Chip Dows fala de um «salto qualitativo» do movimento de ocupação de casas ao estabelecer «uma ligação entre tudo o que constitui au vida na cidade e mecanismos de exploração capitalista» ${ }^{21}$. As comissões de moradores passam a ser, em muitos casos, a base organizativa do movimento social urbano e transformam-se, ainda na análise de Dows, num «verdadeiro duplo poder ao nível da cidade» ${ }^{22}$. Arcary escreve que neste período assistia-se não só ao surgimento generalizado de organismos embrionários de poder alternativo mas também à consolidação e fortalecimento daqueles que já existiam antes de 11 de Março23.

Em resposta à tensão social, o Governo vê-se obrigado a actualizar o salário mínimo e, fortemente apoiado pelo PCP, a aprovar medidas de contenção de preços dos bens alimentares, isto depois da realização de manifestações ao longo do mês de Março contra a «carestia de vida» ${ }^{24}$. Em muitas empresas as lutas conseguem que se mantenha a produção, os postos de trabalho, mas em muitas outras conseguem-se importantes aumentos salariais (neste caso, contra a vontade do PCP, que argumentava que o aumento salarial iria fazer ruir a economia nacional ${ }^{25}$ ), generalização do contrato colectivo, $13 .^{\circ}$ mês, subsí-

18 MuÑoz, Duran, Contención y Transgresión. Las Movilizaciones Sociales y el Estado en las Transiciones Española y Portuguesa, Madrid, CPPC, 2000.

19 «Surto Grevista», Diário de Lisboa, 5 de Maio de 1975, pág. 1, «A TAP disse não à greve», Diário de Lisboa, 6 de Maio de 1975, pág. 1

20 Treffault, Sérgio, Um Outro País, Público, 2004.

21 Dows, Chip, Os Moradores à Conquista da Cidade, Lisboa, Armazém das Letras, 1978, pág. 70.

22 Ibidem, pág. 59

23 ARCARY, Valério, «Quando o Futuro era Agora. Trinta Anos da Revolução Portuguesa», Outubro (2004), pág. 78.

24 «Medidas Revolucionárias. Avanço da revolução», Avante!, Série VII, 24 de Abril de 1975, pág. 8.

25 Discurso no comício do PCP em Vila Franca de Xira, 18 de Maio de 1975, en CunHAL, Álvaro. «A Crise Político Militar». Discursos Políticos , 5, Lisboa, Avante!, 1976, pág. 46. 
dio de Natal. Também foram conseguidas melhorias generalizadas ao nível da previdência, assistência na maternidade, doença e invalidez. É neste período que os trabalhadores conseguem o subsídio de desemprego.

Estes factos, combinados com a derrota do golpe de 11 de Março de 1975, vão provocar a transformação de uma crise de regime numa crise geral do Estado, traduzindo-se na maior crise governativa da revolução, com a saída do PS e mais tarde do PPD (liberais) do IV Governo, o que leva à sua queda em Julho de 1975 e à Constituição do frágil V Governo a 8 de Agosto de 1975. O PS desloca-se da aliança com o PCP em direcção a um amplo bloco social que reúne sectores da direita e da Igreja - e o PCP fica sozinho, restando-lhe como aliados sectores em que o partido não confiava ou que não controlava, como sectores da esquerda militar e parte da extrema-esquerda. A par da crise política surgem as divisões, que se vieram a revelar insanáveis, no seio do próprio MFA.

Para tentar fazer o PS recuar, o PCP vai usar três tipos de recursos tácticos: 1) ameaça, em Julho de 1975, apoiar a constituição de um regime de tipo bonapartista, um governo de forte pendor militar ${ }^{26}$; 2) garantir ao PS o apoio do PCP à estabilização da produção nacional, através da política da «batalha da produção», em que o PCP se opõe às greves e manifestações, defende a produtividade das empresas privadas e tenta obstaculizar as formas de controlo operário nas empresas nacionalizadas; 3 ) apoiar medidas de controlo militar sobre o movimento operário (esta tentativa de militarização do trabalho é traduzida no Documento Guia Povo-MFA)27.

Destas três, porém, a que se transforma em táctica central do partido para tentar reverter o clima de tensão social que antecede o Verão Quente é a política de estabilização da economia levada a cabo pelo PCP, a qual passava por impedir todos os entraves à manutenção da produção, quer esses entraves viessem de sectores da burguesia (sabotagem económica, descapitalização de empresas), quer viessem dos sectores operários (greves e reivindicações, nomeadamente salariais).

O partido defenderá o sector nacionalizado, que passou a ocupar em 1975 à volta de 300000 trabalhadores, cerca de $8 \%$ da população activa, e gerava um valor acrescentado bruto de entre 20 e $25 \%$ do PIB. Como refere Silva Lopes, Portugal ficou com um dos sectores empresariais de mais elevada di-

26 «Discurso no comício do PCP na Praça do Campo Pequeno», 28 de Junho de 1975, en Cunhal, Álvaro, «A Crise Politico Militar». Discursos Políticos 5, Lisboa, Edições Avante!, 1976, págs. 94-95.

27 Nevas, Orlando (org.), Textos Históricos da Revolução, Lisboa, Diabril, 1976, págs. 50-1, cit. por RezolA, Inácia, Os Militares na Revolução de Abril, Lisboa, Campo de Comunicação, 2006, pág. 276; CunHAL, Álvaro, A Revolução Portuguesa. Passado e Futuro, Lisboa, Edições Avante!, 1994, pág. 177; "Nota sobre a assembleia do MFA de 8 de Julho». Comissão Política do CC do PCP, 9 de Julho de 1975. en Documentos do CC do PCP. 3. ${ }^{\circ}$ Volume, Julho/Dezembro de 1975. Lisboa: Edições Avante! 
mensão da Europa Ocidental, mas mesmo assim não muito distinto do que se passava com a França, Itália, Reino Unido e Alemanha. Nesses países, em média, o sector público empregava $10 \%$ da mão-de-obra ${ }^{28}$. Mas o partido não defenderá a nacionalização de mais nenhum sector. Fará uma campanha nacional, que será articulada com os restantes membros do PS, PPD e Conselho da Revolução, para que em todas as empresas privadas houvesse um aumento da produtividade, sem questionar a natureza da propriedade nessas empresas, que empregavam ao todo $92 \%$ da mão-de-obra nacional.

A direcção comunista, neste contexto da «batalha da produção», opor-se-á às formas de controlo operário dos trabalhadores nas empresas nacionalizadas defendendo antes que estas deveriam ser geridas numa forma sui generis de cogestão que incluía representantes dos sindicatos e do Estado. Uma proposta com um paralelo histórico no Chile - quando das nacionalizações levadas a cabo pelo Governo de Salvador Allende, as empresas nacionalizadas passaram a ser geridas por 4 representantes dos trabalhadores e 4 representantes do Estado.

O PCP defenderá as nacionalizações — sem controlo efectivo da produção e da distribuição pelos trabalhadores e submetidas à «batalha da produção»—, sob a fundamentação teórica de que se tratava de uma medida que seria parte de uma etapa na construção do socialismo, uma vez que o Estado não era capitalista, antes estava em transição para o socialismo. Detenhamo-nos no discurso do PCP, em pleno processo revolucionário, em 1975, a propósito da nacionalização dos caminhos-de-ferro: «Nacionalizar uma empresa quer dizer que essa empresa deixa de pertencer a um patrão, a um capitalista ou a um grupo de capitalistas para pertencer unicamente à Nação, isto é, ao povo» ${ }^{29}$.

Portanto, os operários estavam a trabalhar não para o patrão mas para a nação: «A batalha da economia e da produção vai ser nos tempos imediatos o factor decisivo do processo revolucionário. Ou os trabalhadores encaram de uma forma nova a sua conduta no trabalho ou todos os esforços para levantar o nível de vida das classes trabalhadoras soçobrarão. À política de nacionalizações dos sectores básicos e de expropriação dos grandes latifúndios, como formas de democracia económica apontando ao socialismo deverá corresponder uma nova moral no trabalho. Uma acção reivindicativa generalizada e irrealista que ponha em cheque a viabilidade das empresas nacionalizadas, o nível de emprego, perigosamente baixo, e as exigências da produção nacional, como forma de aliviar a nossa dependência do estrangeiro, seria uma aç̧ão contrária à consolidação do processo revolucionário que só à reacção aproveitaria» ${ }^{30}$.

28 Lopes, José da Silva, A Economia Portuguesa desde 1960, Lisboa, Gradiva, 1999, págs. 314-315.

29 «Os ferroviários a favor da nacionalização da CP», Avante!, Série VII, 10 de Abril de 1975, pág. 7.

30 «A unidade da classe operária esteio da unidade de todo o povo». En Avante!, Série VII, 15 de Maio de 1975, pág. 2. 
Esta análise política —o que é do Estado é da Nação; o que é da Nação é do Povo - colocava o PCP na mesma trajectória daqueles que consideravam a possibilidade de uma transição indolor do modo de produção capitalista para o socialista, acarinhando a hipótese — publicamente defendida também pelo MFA e pelo PS - de que esta transição podia ser feita da mesma forma que o MFA tinha protagonizado a transição de regime, ou seja, quase sem mortes (na metrópole), sem a tomada do poder pela classe trabalhadora, em última análise, sem guerra civil. Uma leitura das políticas da União Soviética naquele período e de toda a elaboração teórica histórica do PCP indica já que esta política não era uma originalidade da revolução portuguesa. Tinha raízes na estratégia que vinha desde a «reorganização» do Partido de 1941, de encontrar frentes governativas com sectores da burguesia liberal e da pequena burguesia. Tinha alicerces internacionais bem delimitados, com epicentro justamente na política de coexistência entre os países imperialistas e a URSS. É da URSS que parte a elaboração segundo a qual é possível transitar de forma pacífica para o socialismo. $\mathrm{O}$ argumento, defendido pelo PCP em vários momentos, centrava-se na teoria de que uma vez que a maioria dos países fossem socialistas os outros chegariam a essa etapa sem precisarem de tomar o poder, como se expõe na revista teórica Problemas da Paz e do Socialismo ${ }^{31}$.

O controle estatal sobre as empresas nacionalizadas, ao contrário do que defendia o Partido Comunista, parece ter tido o efeito de diminuir o controlo operário e limitar as acções colectivas dos trabalhadores nestas empresas. Como pesquisou Hammond, investigador norte-americano autor de um estudo pioneiro sobre controlo operário e autogestão em Portugal, «o papel directo do Estado nas empresas nacionalizadas e intervencionadas limitou o alcance do controlo operário nelas» ${ }^{32}$.

E o PCP procurou de certa forma que essa limitação tivesse um suporte institucional. O secretário de Estado do Trabalho do IV Governo Provisório, Carlos Carvalhas, membro do PCP e autor do projecto da coligação governamental sobre controlo operário em Maio de 1975, citado no Avante!, esclarece o alcance daquilo que o partido definia como «controlo operário»: «Esta batalha da reestruturação de todo o aparelho produtivo tem como vectores principais produzir melhor, com menores custos» ${ }^{33}$. Carlos Carvalhas apresenta dois projectos de lei que almejavam (nunca irão concretizar-se na totalidade) um controlo estrito dos trabalhadores que dissipava as formas reais de controlo operário. No primeiro projecto de lei, de Maio de 1975, é proposta a consti-

31 Kiernan, Problemas da Paz e do Socialismo, Lisboa, Edições Avante!, n. ${ }^{\circ}$ 1, 1974, pág. 327.

32 Hammond, John, «Worker Control in Portugal: The Revolution and Today», Economic and Industrial Democracy, London, Sage Publications, 1981, pág. 423.

33 «Fazer do trabalho acto revolucionário», Avante!, Série VII, 19 de Junho de 1975, pág. 6. 
tuição oficial de comissões de controlo da produção, que devem participar na elaboração do plano da empresa e «velar pelo desenvolvimento normal da produção e pela sua melhoria qualitativa e quantitativa» ${ }^{34}$. No segundo projecto, no seu artigo $5 .^{\circ}$, estabelece que «a actividade das comissões não poderá nunca ser exercida contra os interesses globais da economia, pelo que não poderá contribuir em caso algum para a paralisação da regular actividade produtiva da empresa». O projecto estabelecia ainda que cabia às comissões de controlo da produção «velar pelo cumprimento do programa do Governo para o sector» ${ }^{35}$.

Apesar dos esforços, porém, a política da «batalha da produção» não conseguiu nem apaziguar as lutas laborais nem inverter o processo de desinvestimento em Portugal. Entre Abril de 1974 e Novembro de 1975 o número de desempregados, em grande medida devido ainda ao impacto da crise de 1973, sobe de 40 mil para 320 mil $^{36}$. Em Portugal, a taxa de variação do Produto Interno Bruto passa de 11,2\% em 1973 para 1,1\% em 1974 e -4,3\% em 1975. A deterioração das condições económicas era um dos factores objectivos de agravamento da crise de Estado. Em Junho de 1975, a diplomacia inglesa, em documentos confidenciais, descreve desta forma a situação política em Portugal: «A situação em Portugal para os investidores continua a deteriorar-se (...) As principais dificuldades continuam a ser os aumentos sucessivos de salários, drásticos problemas laborais e uma queda acentuada na produtividade. Em muitos casos os gestores e empresários sofrem intimidação física por parte das comissões de trabalhadores - ou foram fechados nas suas instalações ou receberam ameaças por telefone. A atitude das autoridades portuguesas tem sido frequentemente vaga e muito ineficiente. Na verdade, até houve um caso em que discussões confidenciais entre as empresas britânicas e as autoridades portuguesas foram parar à comissão de trabalhadores» ${ }^{37}$.

No dia 10 de Julho de 1975, o PS decide abandonar formalmente o IV Governo Provisório ${ }^{38}$. Oficialmente, a razão apresentada é o diferendo em torno do conflito do caso República, que vai opor a extrema-esquerda, o PCP e o PS, que acusa o PCP de querer ter um domínio ditatorial sobre os meios de

34 Documento do Ministério do Trabalho, en PATRIARCA, Fátima, «Controlo operário em Portugal (I)», Análise Social, vol. XII (3.º 1976 (n. $\left.{ }^{\circ} 47\right)$, págs. 765-816.

35 Documento do Ministério do Trabalho (2. ${ }^{\circ}$ projecto de lei), en PATRIARCA, Fátima, «Controlo operário em Portugal (I)», págs. 765-816.

36 LOPES, José da Silva, A Economia Portuguesa desde 1960, Lisboa, Gradiva, 1999.

37 Records of the Prime Ministers Office: Correspondence and Papers PREM 16/602. Visit to UK by Portuguese Foreign Minister, Major Melo Antunes: meeting with Prime Minister on 27 June 1975. Visit to UK by Portuguese Foreign Minister, Major Melo Antunes: meeting with Prime Minister on 27 June 1975 PORTUGAL Records of the Prime Ministers. Date: 1975.Source: The Catalogue of The National Archives.

38 «O caso do jornal Republica», Avante!, Série VII, 22 de Maio de 1975, pág. 5. 
comunicação. O peso crescente do PCP em inúmeras estruturas do Estado e o controle directo ou a influência politica nesta altura sobre a maioria dos jornais diários era evidente. Porém, o caso República não era o mais óbvio de domínio comunista da comunicação social. Melo Antunes, em conversa com o primeiro-ministro britânico, defende que «Os comunistas foram de facto ultrapassados pelos trabalhadores, que foram mais para a esquerda», segundo Melo Antunes porque os maoístas, apesar de oriundos da «burguesia e com educação universitária, conseguiram penetrar profundamente entre os trabalhadores» ${ }^{39}$.

Mas o pretexto sustentava-se numa situação real — evitar a escalada revolucionária, assumindo o PS que a estratégia de apoiar um governo de frente popular com os comunistas tinha de ser reequacionada. O PCP será acusado pela direcção socialista de querer implantar em Portugal uma ditadura comunista e o PS assume-se agora como a direcção capaz de resgatar a liberdade das malhas da colectivização, do controlo sindical, do anticatolicismo, da ditadura dos meios de comunicação social ${ }^{40}$, procurando desta forma consolidar o apoio dos sectores intermédios da sociedade portuguesa. A campanha anticomunista estrutura-se nesse Verão Quente ${ }^{41}$ apoiada não pela disposição do PCP de dirigir uma transição para o socialismo em Portugal, mas pela disputa entre PCP e PS sobre as posições-chave no aparelho de Estado e militar e pelo descontrole cada vez maior sobre o movimento operário, popular e estudantil.

\section{UM GOVERNO DOS COMUNISTAS OU UM GOVERNO COM OS COMUNISTAS?}

No dia 25 de Julho de 1975, a Assembleia do MFA reúne-se e da reunião sai a proposta de constituição de um triunvirato, constituído por Costa Gomes, Vasco Gonçalves e Otelo Saraiva de Carvalho, para tentar pôr fim à crise política que tinha resultado do fim da coligação que sustentava o IV Go-

39 Records of the Prime Ministers Office: Correspondence and Papers PREM 16/602. Visit to UK by Portuguese Foreign Minister, Major Melo Antunes: meeting with Prime Minister on 27 June 1975. Visit to UK by Portuguese Foreign Minister, Major Melo Antunes: meeting with Prime Minister on 27 June 1975 PORTUGAL Records of the Prime MinistersDate: 1975.Source: The Catalogue of The National Archives.

40 «Mário Soares com a Imprensa», Diário de Lisboa, 7 de Maio de 1975, pág. 1.

41 «A estruturação do anti-comunismo terrorista baseou-se em quatro componentes: o apoio da hierarquia eclesiástica, cujo epicentro foi o episcopado de Braga; a ajuda operacional, técnica e económica de Espanha, que além disso proporcionava uma retaguarda segura; a colaboração com os militares contrários ao 25 de Abril, que vertebraram todo o movimento tornando-o eficaz; e por último a concordância de todas as forças políticas desde os socialistas até à direita, maioritárias no distritos do centro e norte do país» (CERVELLÓ, Josep Sánchez, A Revolução Portuguesa e a sua Influência na Transição Espanhola (1961-1976), Lisboa, Assírio e Alvim, 1993, pág. 237). 
verno Provisório. O PCP apoia esta decisão e caracteriza que o «inimigo principal» continua a ser a «reacção», pelo que são precisas soluções que façam «respeitar a ordem democrática» ${ }^{42}$. Recuando na sua ameaça de um governo forte, o PCP insiste com o PS para se repor a coligação governamental ${ }^{43}$. A direcção comunista lembra ao PS que Portugal poderia ser o novo Chile, se os socialistas recusassem uma nova aliança com o PCP44.

Nas negociações para a formação do V Governo, Vasco Gonçalves, primeiro-ministro, militar e homem de confiança do PCP, procurará fazer um governo plural, dentro da órbita da esquerda, mas sem sucesso. A 29 de Julho de 1975, Melo Antunes, do PS, abandona a pasta dos Negócios Estrangeiros; no dia imediato, é seguido por Jorge Sampaio e João Cravinho, do MES (Movimento de Esquerda Socialista). A 4 de Agosto de 1975 é a vez de Otelo Saraiva de Carvalho, próximo de sectores da extrema-esquerda, recusar o apoio do COPCON ao Governo ${ }^{45}$.

8 de Agosto é o dia da tomada de posse do Governo, chefiado por Vasco Gonçalves. Era composto por militares, independentes e membros do $\mathrm{MDP} / \mathrm{CDE}$, mas politicamente só tem o apoio formal do PCP e do MDP/CDE. Nesse dia, Melo Antunes, Vasco Lourenço, Sousa e Castro, Vítor Alves, Pezarat Correia, Franco Charais, Canto e Castro, Costa Neves e Vítor Crespo tornam público um documento que dizia rejeitar «o modelo de sociedade socialista de tipo Europa Oriental» e rejeitar o modelo «de sociedade social-democrata em vigor na Europa Ocidental», publicado na véspera, tarde, numa edição especial do Jornal Novo ${ }^{46}$. Ficará conhecido como Documento dos Nove. O mesmo jornal publica nesse dia uma nota de Mário Soares exigindo a demissão de Vasco Gonçalves ${ }^{47}$. Desta forma, quando finalmente o V Governo toma posse, nesse mesmo dia 8 de Agosto de 1975, já não tem condições sociais para governar.

42 «Nota da Comissão Política», 27 de Julho de 1975, In Avante!, Série VII, 31 de Julho de 1975, pág. 4.

43 «Discurso no comício do PCP de Homenagem a Germano Vidigal em Montemor-oNovo», 8 de Junho de 1975, en Cunhal, Álvaro, A Crise Politico Militar. Discursos Políticos 5, Lisboa, Edições Avante!, 1976, pág. 81, pág. 92,

44 «Combater o anticomunismo é lutar pela revolução», Avante!, Série VII, 10 de Julho de 1975, pág. 3.

45 Cronologia Pulsar da Revolução, Julho de 1975, Centro de Documentação 25 de Abril. En http://www1.ci.uc.pt/cd25a/wikka.php?wakka=PulsarJulho75, consultado a 12 de Novembro de 2009.

46 Rezola, Maria Inácia, Os Militares na Revolução de Abril: o Conselho da Revolução e a Transição para a Democracia em Portugal, Lisboa, Campo da Comunicação, 2006, pág. 352-353.

47 Cronologia Pulsar da Revolução, Julho de 1975, Centro de Documentação 25 de Abril, en http://www1.ci.uc.pt/cd25a/wikka.php?wakka=PulsarJulho75, consultado a 12 de Novembro de 2009. 
Quer isto dizer que o Partido Comunista Português quis com este Governo fazer um 'golpe de Praga'? Quis «tomar o poder»?

A função de todos os partidos, como afirma René Rémond, é exactamente «chegar ao poder»: «A política é a actividade que se relaciona com a conquista, o exercício, a prática do poder, assim os partidos são políticos porque têm como finalidade, e seus membros como motivação, chegar ao poder. Mas não a qualquer poder! (...) Só é política a relação com o poder na sociedade global (...) Na experiência histórica ocidental, ela se confunde com a nação e tem como instrumento e símbolo o Estado» ${ }^{48}$. Por isso, para compreendermos o que se passou na política do Partido Comunista no Verão Quente é indispensável precisar as questões: o PCP estava disposto a dirigir a tomada do poder pela classe trabalhadora em Portugal em 1975, para iniciar um processo de transição para o socialismo com a expropriação da burguesia, à semelhança do Partido Bolchevique na URSS em 1917? O PCP quis expropriar a burguesia, mas em vez de dirigir as organizações de trabalhadores planeou um «golpe de Praga» apoiado na esquerda militar? O PCP quis paulatinamente ocupar espaços no aparelho de Estado, porque acreditava que essa era uma forma de quebrar a unidade deste, alterando a natureza de classe do aparelho de Estado?

O Avante!, jornal oficial do PCP (com tiragens de dezenas de milhares de exemplares), nunca teve uma capa de explícito apoio ao V Governo ou a Vasco Gonçalves, mas sai um Avante! especial de questionamento desse mesmo Governo. O jornal que sai no dia 7 de Agosto de 1975 tem como eixo a defesa do PCP face aos violentos ataques anticomunistas de que está a ser alvo nas suas sedes"9; o número que é publicado uma semana mais tarde, a 14 de Agosto, é centrado no mesmo assunto ${ }^{50}$.

No meio, a 11 de Agosto, é publicado um número especial do jornal ${ }^{51}$ Avante! onde vem o relatório de Álvaro Cunhal ao Comité Central extraordinário de 10 de Agosto, reunido em Alhandra (periferia de Lisboa, bastião do Partido), onde o líder comunista questiona a viabilidade do V Governo. Nesse relatório Cunhal explica, numa passagem só mais tarde publicada integralmente, que «pensámos já nesse momento (antes da constituição do Governo) guardar um campo de manobra política para o nosso partido que não nos atrelasse necessariamente a uma previsível queda do Governo de Vasco Gonçalves» ${ }^{52}$. O partido considera que a crise estava em risco de terminar numa gue-

48 RÉmond, René, Por uma História Política, Rio de Janeiro, FGV Editora, 2. a edição, 2003, pág. 444.

49 Avante!, Série VII, 7 de Agosto de 1975, pág. 1; Nota: 10\% das sedes do PCP forma destruídas pela violenta campanha anti-comunista durante o Verão Quente.

50 Avante!, Série VII, 14 de Agosto de 1975, pág. 1.

51 Avante!, Série VII, 11 de Agosto de 1975, número especial, pág. 1.

52 «Intervenção na reunião plenária do CC do PCP», 10 de Agosto de 1975, en CunHAL, Álvaro. «A Crise Politico Militar», pág. 139. 
rra civil, num confronto armado. O líder do PCP define como prioritária a constituição de uma solução política que reponha no essencial a forma de coligação governamental anterior, entre PCP e PS, e a estreita coordenação desta com o MFA. Pede aos seus militantes para porem fim ao «sectarismo» e «distinguirem o inimigo principal», as «forças fascistas e fascizantes», das «forças hesitantes acerca do processo revolucionário e do caminho para o socialismo». Cunhal pede ao Comité Central que deixe aos órgãos executivos espaço para decidir e «conservar margem de iniciativa, inclusivamente de negociações» num eventual golpe militar vindo de sectores moderados do MFA e do PS ou de uma situação em que este sector ganhe a iniciativa política: «Isto significa a hipótese (...) de certas pontes com forças ou elementos que estão colocados hoje num sector que contraria o processo. Isto ao nível civil e ao nível militar (...) E acontece mesmo que certa parte militar, que podemos ter como progressista, se volte contra o partido ou deixe o partido isolado» ${ }^{53}$.

No informe, o líder comunista admite ainda que sem estar resolvida a questão militar, o V Governo era um Governo falhado à partida, que iria fragilizar o PCP: «Todo o esquema das forças conservadoras e reaccionárias era mostrar este Governo como o Governo dos comunistas, sem apoio militar, e deixá-lo cair depois. O fracasso deste Governo seria o fracasso do Partido Comunista, que seria arrastado nesta derrota com todas as suas consequências» ${ }^{54}$. Documentos desclassificados da CIA, que vieram a público recentemente no estudo de Tiago Moreira de Sá (2009), confirmam esta tese: «Num documento de análise à composição do gabinete chefiado por Vasco Gonçalves, a CIA escrevia que este era «dominado por militares radicais e por testas de ferro e apoiantes do PCP», sendo que «os socialistas e os populares democratas, cujos partidos obtiveram 64\% dos votos em Abril, não faziam parte do Governo.» Ainda de acordo com a Agência, a decisão de Costa Gomes de empossar novamente o militar aliado dos comunistas era uma «armadilha» do Presidente da República, que estava «convencido que o Governo de Gonçalves se ia desfazer sob o peso dos muitos problemas de Portugal» e «o grupo com uma orientação democrática ia ser capaz de apanhar os pedaços sem grande resistência» ${ }^{55}$. Esta era também a caracterização que Cunhal fazia do V Governo, desde o início: um governo efémero, que iria fragilizar o PCP.

No dia 20 de Agosto, dez dias depois da reunião do Comité Central de Alhandra, Cunhal, em conferência de imprensa, declara que «um governo de

53 «Intervenção na reunião plenária do Comité Central do PCP», 10 de Agosto de 1975, en Cunhal, Álvaro, «A Crise Politico Militar», págs. 156-157.

54 «Intervenção na reunião plenária do Comité Central do PCP», 10 de Agosto de 1975, en CunHaL, Álvaro, «A Crise Politico Militar», págs. 139.

55 «New Portuguese Government Causing Deep Divisions in Military», CIA, August 8, 1975. www.foia.cia.gov, In SÁ, Tiago Moreira de, Os Estados Unidos da América e a Democracia Portuguesa (1974-1976), Lisboa, MNE, Instituto Diplomático, 2009. 
coligação do MFA e principais partidos políticos foi justamente considerado o sistema de alianças mais adaptado à correlação e arrumação das forças de classe» ${ }^{56}$. E irá surpreender os militantes ao assegurar que se podem combinar os documentos das várias fracções militares.

Perante a exigência da extrema-esquerda, tornada palavra de ordem numa gigantesca manifestação de apoio ao V Governo, a 27 de Agosto, que inclui o PCP e a FUP57, de dissolução da Assembleia Constituinte, o PCP vai contestar que não apoia medidas destrutivas «face à actual Assembleia Constituinte» ${ }^{58}$. Às críticas vindas da sua esquerda o PCP reage em comunicado alegando a necessidade de fazer uma «negociação com os adversários» 59 .

Na conferência de imprensa, no dia 29 de Agosto, às 11 da noite, Álvaro Cunhal assume a queda do V Governo e diz que está disposto a reunir-se com o PS, o Grupo dos 9 e o COPCON para encontrar uma solução governativa: «Temos um grande apreço por este dirigente do MFA acerca da sua acção na direcção dos governos provisórios até hoje, mas não temos opiniões cristalizadas e pensamos que o general Vasco Gonçalves também não. Os revolucionários não defendem lugares» ${ }^{60}$.

No início de Setembro, e enquanto decorriam as negociações da formação do VI Governo, a posição do PCP é a de reivindicar uma ampla participação comunista no elenco governamental; exigir o afastamento do PPD do Governo, considerado um partido que atenta contra a «liberdade e democracia» ${ }^{61}$. As negociações fazem-se com críticas da direcção comunista à esquerda e lançando recados ao PS e Grupo dos 9 de que a participação comunista no VI Governo dependia do grau de compromisso que estes estivessem dispostos a assumir com o PCP.

56 «Declaração sobre a crise política actual», 20 de Agosto de 1975. En Documentos Políticos do Comité Central do PCP, 3. ${ }^{\circ}$ Volume, Julho/Dezembro de 1975, Lisboa, Edições Avante, 1976, págs. 87-98.

57 A FUP transformar-se-á em FUR (Frente Unidade Revolucionária) a 2 de Setembro de 1975, fazendo dela parte FSP, LCI, LUAR, MDP/CDE, MES, PRP57. No seu manifesto defendem a organização armada de organismos de poder popular para auto-defesa; liberdade de reunião de soldados e marinheiros; saneamento e repressão dos fascistas; nacionalização, sem indemnizações e sob controlo dos trabalhadores, das grandes empresas industriais e agrícolas; luta pelo controlo operário e pelo pleno emprego; saída de Portugal da NATO e fim do Pacto Ibérico; apoio ao MPLA, dissolução da Assembleia Constituinte e constituição de um Governo de Unidade Revolucionária.

58 «Para uma crise global soluções globais», Avante!, Série VII, 28 de Agosto de 1975, pág. 2.

59 «Acerca dos acordos de 25 de Agosto», Avante!, Série VII, 4 de Setembro de 1975, pág. 4.

60 Avante!, Série VII, 4 de Setembro de 1975, pág. 3.

61 A solução da crise passa pela negociação», Avante!, Série VII, 11 de Setembro de 1975, pág. 2. 
O VI Governo toma posse no dia 19 de Setembro de 1975, com uma representação diminuta do PCP. O partido ficará apenas representado com um único ministro, Veiga de Oliveira, ministro das Obras Públicas. O PS fica com 5 ministérios (Comunicação Social, Finanças, Transportes e Comunicações, Agricultura e Pescas e Comércio Externo), áreas que controlavam directamente o financiamento dos sectores políticos que o PCP dirigia, nomeadamente o sector da reforma agrária, as empresas nacionalizadas e intervencionadas e a política laboral: «A nossa posição quanto ao Governo é determinada pela quota parte da nossa responsabilidade. Se as nossas responsabilidades diminuem, diminui também, compreensivelmente, a margem do nosso apoio ao VI Governo Provisório» ${ }^{62}$.

No fim de Agosto, depois de aceitar a substituição do V Governo e participar no VI Governo, liderado por Pinheiro de Azevedo, o PCP está no seu momento de maior fragilidade desde o início da revolução, porque o desmembramento do MFA arrasta consigo a «aliança Povo-MFA», deixando os trabalhadores «órfãos» da direcção que o próprio PCP tinha construído. Mesmo autores que não coincidem com a tese que aqui defendemos partilham a análise da fragilidade do PCP neste momento, devido ao desmoronamento do MFA (Cunha, 1992: 259).

Álvaro Cunhal e a direcção do PCP não estavam dispostos a entrar numa guerra civil. Tratava-se por isso de terminar com o V Governo, sofrendo os menores danos possíveis para o PCP. Estes menores danos incluiriam, nesta altura do processo revolucionário, assegurar influência no VI Governo, dirigir de forma controlada a mobilização social que existia para garantir que na sua passagem a um regime democrático podiam manter-se as nacionalizações, concretizar a reforma agrária e garantir a independência de Angola sob direç̧ão do MPLA.

A curta existência do V Governo nunca terá significado uma tentativa de putsch por parte da direcção do PCP, embora sectores da extrema-esquerda e da esquerda militar pudessem ter apoiado essa via. Os meses que se seguem até o golpe de 25 de Novembro de 1975 pôr fim à indisciplina nos quartéis —a sovietização das forças armadas nas palavras do líder socialista Mário Soares ${ }^{63}$ são marcados pela ruptura do MFA, por um lado, e pela crescente crispação do PCP não só com os partidos de extrema-esquerda ${ }^{64}$ mas também, e mais significativamente, com a esquerda militar. Em 1976, no balanço que faz da actuação da esquerda militar na revolução (no capítulo «Avanço impetuoso da revolução» da obra A Revolução Portuguesa. O Passado e o Futuro), Cunhal afirma que o cerco de Novembro à Assembleia da República, tal como outras

62 Editorial, Avante!, 6 de Novembro de 1975.

63 Avilez, Maria João, Soares, Ditadura e Revolução, Lisboa, Público, 1996, pág. 483.

64 O Militante, Série IV, Novembro de 1975, n. ${ }^{\circ}$ 5, pág. 17. 
acções, fora provocado pela esquerda militar e pelos «esquerdistas» a ela associados: «Tanto as lutas de massas como as lutas militares foram negativamente influenciadas por manobras esquerdistas para se assenhorarem do processo e para empurrarem sistematicamente as acções para choques com as forças armadas. Tal sucedeu com o cerco ao VI Governo Provisório em S. Bento pelos deficientes das Forças Armadas e pelos trabalhadores da construção civil, com o caso Rádio Renascença conduzido ao paroxismo pela aventura, com certo verbalismo na 5. ${ }^{\text {a }}$ Divisão, com a 'bagunça' esquerdista pseudo-revolucionária em algumas unidades como o RALIS e a PM» ${ }^{65}$.

Nenhuma das teses avançadas sobre a «tomada de poder» pelo PCP foi corroborada até hoje pelo estudo dos documentos históricos. Tanto a visão que compara o papel de Álvaro Cunhal na revolução portuguesa de 1974 com o de Lenine na revolução bolchevique de 1917 como a que procura semelhanças entre o 'golpe de Praga' de 1948 e o V Governo português de 1975 não encontram comprovação nos documentos. Ambas devem mais, certamente, à disputa política do período pós-revolucionário, que envolve uma acirrada polémica em torno da memória da revolução. De um lado, o PS e o Grupo dos 9, segundo os quais tiveram de abandonar a construção de um projecto socialista e ficar no campo ocidental e da NATO porque a alternativa seria estar submetidos ao Pacto de Varsóvia. Do outro lado, o PCP que, ao mesmo tempo que procurava afastar-se de qualquer protagonismo num processo de tomada de poder, não abandonou o léxico revolucionário, resguardando para si uma imagem de combatividade junto da sua base.

O PCP não quis dirigir uma insurreição feita pelas organizações de base dos trabalhadores com o objectivo de iniciar um processo de transição para uma sociedade socialista. O PCP teve uma política de alianças interclassista e de construção da democracia representativa, embora no quadro de um regime capitalista com forte pendor regulacionista. Aceitou as regras da democracia, daquela democracia burguesa que nas suas palavras era impossível que vingasse em Portugal devido ao atraso do país, mas que se verificou ser uma realidade sólida e estável. Estas regras incluíam o respeito pela propriedade privada e pelo parlamentarismo, em contradição com o papel de Lenine e do Partido Bolchevique. Lenine dirigiu, em 1917, a revolução russa defendendo o transcrescimento da revolução burguesa em revolução operária, com a justificação teórica de que a revolução não resolveria as tarefas democráticas, burguesas, sem o acesso do proletariado ao poder, e de que o proletariado, uma vez no poder, não poderia confinar-se ao modelo de uma revolução burguesa. Nos dias 3 e 4 de Abril de 1917, no documento que ficou conhecido como as «Teses de Abril», Lenine defende, contra a então maioria da direc-

65 Cunhal, Álvaro, A Verdade e a Mentira na Revolução de Abril (A contra-revolução confessa-se), Lisboa, Edições Avante!, 1999, pág. 208. 
ção do Partido Bolchevique (sobretudo contra Kamenev e Estaline, que defendiam o apoio e mesmo a participação no Governo Provisório do príncipe Lvov), esta estratégia que se saldou no famoso «Todo o poder aos sovietes» e na não participação dos bolcheviques no Governo Provisório de Kerensky66.

Na Checoslováquia, os comunistas e os social-democratas tinham ganho as eleições em 1946, mas tinha sido constituído um governo de unidade nacional que incluía partidos de direita. Em 1948, os comunistas, que depois se unificam com os socialistas formando um partido único, impõem ao presidente Edvard Benes a nomeação de um governo dominado exclusivamente por comunistas e preparam uma mobilização de massas na rua para lutar por esse governo, a par de uma depuração dentro do aparelho de Estado ${ }^{67}$. Todo o processo, que não deixou de ser feito com amplo apoio dos trabalhadores checos, teve o amparo diplomático da URSS e a segurança de estar protegido, em caso de falhar, pelo Exército Vermelho.

Como se vê, as circunstâncias de Portugal são muito diferentes. Os comunistas não tinham ganho as eleições em Portugal, o PCP procurou estar num governo de frente com o PS e o Grupo dos 9 e, não menos importante, Portugal estava no quadro da Aliança Atlântica. A fidelidade do PCP à URSS é também a fidelidade do PCP a 'Ialta e Potsdam', ou seja, Portugal estava na parte do Mundo definida pelo novo 'meridiano de Tordesilhas' negociado por Roosevelt, Churchill e Estaline no final da II Guerra Mundial como sendo de domínio ocidental - e a política da URSS sempre foi de não interferir na área de influência das potências ocidentais definida nos acordos de Ialta e Potsdam. A Checoslováquia estava do outro lado da 'cortina de ferro'. Quando se encontram para assinar a Acta Final da Conferência sobre Segurança e Cooperação na Europa, os líderes europeus e norte-americanos, em conjugação com os soviéticos, estavam conscientes dos problemas da revolução portuguesa, mas entre esses problemas não estava o medo de que o PCP tomasse o poder, porque todos concordavam com a divisão feita em Ialta, que colocava Portugal no bloco militar da NATO ${ }^{68}$. Nas suas recentes memórias, Anatoli Tchernaiev, alto funcionário da Secção Internacional do CC do PCUS, escreve lacónico que entre as razões para a URSS aceitar a social-democracia em Portugal estava um facto: «A Checoslováquia é nossa, Portugal é vosso» ${ }^{69}$ (dos norte-americanos).

66 Harman, Chris, The Peoples History of the World, London-Sidney, Bookmarks, 1999.

67 SAlvadori, Massimo (org.), Do Início ao Fim da Guerra-fria. História Universal, vol 16, Lisboa, Planeta DeAgostini, 2005, pág. 99.

68 SÁ, Tiago Moreira de, Os Estados Unidos da América e a Democracia Portuguesa (1974-1976), Lisboa, MNE, Instituto Diplomático, 2009, págs. 377-378 e pág. 409.

69 MilHAZES, José, «História: União Soviética entregou Portugal à Social-democracia», Agência Lusa LGR5886 5 DI - Correspondentes Internacionais 476 LUSA 11075886, 24 de Maio de 2010. 
É de salientar ainda que o V Governo suscita oposição ao nível da sua composição e não da sua política económica. Diferentemente da colectivização dos meios de produção, levada a cabo sob a direcção dos comunistas checos em $1948^{70}$, Vasco Gonçalves, no discurso de tomada de posse, para além da tarefa central de evitar a crise no seio das forças armadas e do Estado, ressalta a urgência de «impor medidas de austeridade» ${ }^{71}$ e uma semana depois discursa a favor da necessidade do respeito pela propriedade privada72. É acompanhado nesta política pelo PCP, que continua a definir «o aumento da produtividade como condição do triunfo da revolução socialista» ${ }^{73}$ em curso, sem questionar a propriedade privada.

O PCP quis paulatinamente ganhar influência no aparelho de Estado?

Depende do momento do processo revolucionário e em que sectores do aparelho de Estado. Por exemplo, nas autarquias locais não foi paulatinamente, mas bastante depressa, sobretudo através dos quadros do MDP nas estruturas de poder local, que iam sendo saneadas sob impulso popular e dos próprios PCP e MDP. Também procurou ter influência decisiva nas Forças Armadas, nos ministérios que dirigiam os sectores económicos mais importantes - Trabalho, Agricultura e, claro, Finanças. E ainda na comunicação social. Mas nada permite concluir que nesse aspecto foi distinto do PS ou do PPD. Como recorda o sociólogo António Barreto, a ocupação institucional foi um passo de todos quantos eram oposicionistas ao Estado Novo, «com vantagens para o PC e o MFA, mas no qual participaram também o PS e o PPD» ${ }^{74}$. Isso será bem visível quando, durante o VI Governo, a mesma táctica de acção dentro do aparelho de Estado é levada ao extremo pelo PS e pelo Grupo dos 9, quando se generalizam os saneamentos «à esquerda» e os lugares antes ocupados pelo PCP passam a ser ocupados por quadros afectos ao PS. Importa referir que mais dependente do Estado do que o PCP para sobreviver era o próprio PS, uma vez que os comunistas dirigiam a Intersindical e, no Sul, as Unidades Colectivas de Produção, e o PS não. Por isso, para os socialistas, ter influência na comunicação social, dirigir autarquias, ganhar eleições era tão ou mais importante do que para o PCP. Isso não significa que o PCP não

70 SAlvadori, Massimo (org.), Do Início ao Fim da Guerra-fria. História Universal, vol. 16, Lisboa, Planeta DeAgostini, 2005, pág. 98.

71 «Discurso na tomada de posse do V Governo Provisório», GonÇALVES, Vasco, Discursos. Conferências. Entrevistas, Lisboa, Seara Nova, 1977, pág. 358.

72 «Palavras pronunciadas no pavilhão gimnodesportivo da escola D. António Costa, em Almada», 18 de Agosto de 1975, GonçAlves, Vasco, Discursos. Conferências. Entrevistas, Lisboa, Seara Nova, 1977, págs. 373-4.

73 «O aumento da produtividade como condição do triunfo da revolução socialista», Avante!, Série VII, 7 de Agosto de 1975, pág. 2.

74 BARreto, António, «Classe e Estado: os Sindicatos na Reforma Agrária», Análise Social, vol. XX (80), 1984 - 1, pág. 42. 
tenha feito todos os esforços para aumentar essa influência. Vinha com uma clara vantagem, que era ter sido o único que no momento da queda da ditadura estava apto a preencher os lugares que iam caindo. O PCP disputou, numa luta aguerrida com o PS, a organização do Estado, mas isso não significa que tenha querido «tomar o poder», ou seja, transformar a natureza de classe do Estado. Isso é claro pela sua relação com os organismos de poder dual. Uma das contribuições do estudo empírico do PCP e da revolução portuguesa para a teoria das revoluções é exactamente a de que a ocupação do aparelho de Estado - que por força da forma como se dá a queda da ditadura, em particular os saneamentos, foi, no caso de Portugal, extensíssima - por forças afectas a um Partido Comunista não muda a natureza de classe desse Estado. Porque esse Estado conseguiu, com contradições, gerir e enquadrar essa ocupação de lugares chave sem colocar em causa a sua unidade.

\section{PCE E PCP: REEQUACIONAR AS DIFERENÇAS}

A decisão do PCP em não apoiar uma ruptura sistémica em Agosto de 1975 levanta novas interrogações aos historiadores que se interessam pela análise comparativa dos partidos comunistas ibéricos. Se os documentos hoje analisados colocam em causa a tese de um PCP alinhado em construir em Portugal um regime satélite da URSS, as diferenças entre os dois partidos devem também ser reequacionadas. Estamos entre dois partidos com histórias, tácticas, políticas por vezes substancialmente divergentes, mas não podemos reduzir estas diferenças a uma análise tendencialmente simplista que associa o PCP de Álvaro Cunhal a tácticas leninistas e o PCE ao reformismo eurocomunista.

As diferenças entre a história política do PCP, dirigido por Álvaro Cunhal, e o PCE, liderado por Santiago Carrilo, estão indelevelmente marcadas pelos acontecimentos históricos nos dois países ibéricos ao longo do século XX. Se é verdade que Portugal e Espanha tiveram, durante uma parte do século XX, regimes ditatoriais muito semelhantes ${ }^{75}$ —as únicas vezes em toda a sua vida que Salazar saiu de Portugal foi para visitar Franco- também é indiscutível que a dinâmica da prolongada guerra civil espanhola e a rápida derrota da insurreição da greve geral de 1934 em Portugal moldaram de forma distinta o PCE e o PCP.

A derrota na guerra civil espanhola é, para o lado republicano, uma derrota de dimensões catastróficas à escala do século $\mathrm{XX}^{76}$. Centenas de milhares de

75 Redondo, Juan Carlos Jiménez, Franco e Salazar. As Relações Luso-Espanholas durante a Guerra-fria, Lisboa, Assírio e Alvim, 1196.

76 PReston, Paul, Franco, London, HarperCollins, 1993. 
mortos e exilados, numa guerra que dura 3 anos. A derrota do movimento operário português é mais lenta - um fenómeno de tipo erosivo, que se inicia pelas mãos do regime republicano em 1910 e termina em 1934, quando a política reprime brutalmente, mas com relativa facilidade, o levantamento insurreccional na tradicional vila vidreira da Marinha Grande, no centro do país. Não se abre em Portugal uma situação de guerra civil. Como demonstra Paloma Aguilar, a memória da brutalidade da guerra civil teve um efeito de autocontenção em sectores determinantes da oposição de esquerda antifranquista $^{77}$. Os militantes comunistas eram o alvo principal da repressão pela polícia política de Salazar —as investigações de Irene Pimental comprovam-no ${ }^{78}$ com tortura, assassinatos, dezenas de anos de cárcere dos principais dirigentes. Mas o movimento operário, camponês e popular português não viveu o massacre que teve lugar em Espanha nos anos 30 do século XX.

Por outro lado, grande parte das lideranças espanholas do PCE — junto aliás com proeminentes republicanos, socialistas, intelectuais, escritoresescolhera a França como lugar do longo exílio imposto pelo regime de ditadura. Paris será também a capital de acolhimento de uma parte da intelectualidade portuguesa, mas a maior parte dos quadros comunistas exilados terá na URSS e nas suas repúblicas satélites, como a República Checa e a República Democrática Alemã, a sua terra de exílio. A tradição de formação intelectual e cultural dos quadros dirigentes dos dois partidos — partidos que, recorde-se, resistiram como organizações nas duras condições da clandestinidade, sob regimes ditatoriais-, é distinta, estando desde cedo o PCP mais ligados a Moscovo do que o PCE. A questão do financiamento tem contornos que ainda hoje não conhecemos bem, mas tudo indica o PCP era muito mais dependente do financiamento do aparelho internacional soviético do que o PCE, que desde muito cedo estabelece relações próximas com as cúpulas do PCF e do PCI, estes já com uma longa tradição de ocupação de espaços no aparelho de estado francês e italiano, o que lhes garantia alguma autonomia, incluindo autonomia financeira face à URSS.

Os partidos são as suas memórias, a tenacidade dos seus militantes, a formação intelectual e cultural dos dirigentes, as origens do seu financiamento, as suas ligações internacionais. Mas para além destes factores, que dizem respeito ao passado e à construção destas organizações, parece ter sido ainda mais importante, no traçado do rumo político do PCP e do PCE, a forma como ambas as ditaduras caem no segundo biénio da década de 70 do século XX, e que está intimamente ligada às contradições que os seus Estados tinham que suportar.

77 Agullar, Paloma, Memoria y Olvido de la Guerra Civil Española, Madrid, Alianza Editorial, 1996.

78 Pimentel, Irene Flunster, História da PIDE, Lisboa, Círculo de Leitores/Temas e Debates, 2007. 
Portugal e Espanha eram dois países semiperiféricos, até aos anos 60 do século XX essencialmente agrícolas, que deram um salto em termos de urbanização e industrialização durante toda a década de 60, criando uma classe trabalhadora jovem e concentrada nos centros urbanos ${ }^{79}$. Eram países marcados por problemas históricos estruturais como a «questão agrária» no Sul (na Andaluzia e no Alentejo), moldados por fortes assimetrias regionais, e ambos com uma tradicional dependência tecnológica do exterior. São países que sofrem profundamente com o impacto da crise de $1973^{80}$.

São porém distintos noutros aspectos, nomeadamente aquele que veio a revelar-se qualitativo, a dimensão das colónias. Portugal era uma potência colonial, detendo em África Angola, Moçambique, Cabo Verde, São Tomé e Guiné Bissau - enquanto a Espanha tinha apenas o Sara Ocidental, um território a sul de Marrocos, e a diminuta Guiné Equatorial. Outro factor distinto entre os países ibéricos foi a existência do problema de nacionalidades em Espanha, sobretudo na Catalunha e no País Basco, questão inexistente em Portugal, um país razoavelmente homogéneo há centenas de anos.

A política dos dois partidos ibéricos parece-nos hoje, mais do que estrategicamente alinhada com uma via mais europeísta e outra mais pró-soviética, uma política que responde primordialmente à questão nacional, privilegiando as direcções dos comunistas, em ambos os casos, os equilíbrios internos dos seus países, em detrimento de qualquer estratégia internacionalista ou revolucionária.

Em Portugal, a dimensão de crise de Estado é mais aprofundada do que em Espanha, porque ela inicia-se na coluna vertebral do Estado ${ }^{81} \mathrm{com}$ a derrota na guerra colonial. A queda do regime dá-se sob a forma de um golpe de Estado, que abre as portas a uma situação revolucionária. Entre outras medidas, isto significou em Portugal uma instauração praticamente imediata das liberdades democráticas por que o PCP tinha lutado durante quase quatro décadas na clandestinidade: liberdade de expressão, reunião, associação, legalização de facto dos partidos políticos, previsão de eleições para a Assembleia Constituinte, fim da polícia política, fim da censura. Este processo é tão imediato, e acompanhado de uma mobilização social sem precedentes na história do país, que menos de um mês depois da queda do regime em Portugal, o PCP

79 Fernández Clemente, Eloy, «Problemas y Ritmos de la Modernización Económica Peninsular en el Siglo XX», en Torre GómeZ, Hipólito de la (ed.), Portugal Y España Contemporáneos, Madrid, Ayer, Marcial Pons, 2000.

80 LLUCH, Ernest, «Transición Económica y Transición Política: La Anomalia 19781980», en TuSSEL, Javier у SoTO, Álvaro (eds.), História de la Transición 1975-1986, Madrid, Alianza Universidad, 1996, pág. 252.

81 Rosas, Fernando, Pensamento e Acção Política. Portugal Século XX (1890-1976), Lisboa, Editorial Notícias, 2004, pág. 136. 
toma posse, junto com o PS e o PPD, no I Governo Provisório, quebrando um tabu com perto de 30 anos de não haver comunistas em governos ocidentais.

Mário Soares, líder do Partido Socialista, inicia um périplo pela Europa no dia 2 de Maio de 1974, uma semana depois da queda do regime. Em Bona defende a participação comunista no Governo por duas razões: «Soares disse que os planos da Junta para formar um governo provisório dentro de uma ou duas semanas incluíam elementos do espectro político português, da esquerda à direita. Na esquerda, o Governo incluiria comunistas e socialistas. Soares avançou duas razões para a inclusão dos comunistas no Governo: primeiro, como o novo governo era nomeado em vez de eleito, achava-se que se os comunistas não entrassem no Governo iam pressionar para eleições livres imediatas. Segundo, os próximos meses iam ser decisivos para o governo lidar com os inúmeros problemas de Portugal e seria muito melhor ter os comunistas a partilhar as responsabilidades pelos sucessos e falhanços do seu governo do que estarem numa posição crítica.» ${ }^{82}$

Em Espanha o final do franquismo resulta de uma negociação, em que hoje parece indiscutível o peso jogado pelo movimento operário e pelos movimentos sociais ${ }^{83}$ (incluindo a própria revolução portuguesa), mas em que o Estado subsiste sem a dimensão de crise do Estado português. O PCE só será legalizado a 9 de Abril de 1977, apesar de ter sido rapidamente elevado, ainda nesse ano e pelo mesmo Estado que tinha proibido a sua existência, a um lugar de parceiro de negociação incontornável, nos Pactos de Moncloa.

PCP e PCE são, em ambos os países, os partidos que dirigem uma maior fracção das classes trabalhadoras e com um grau de influência determinante nos maiores sindicatos. Mas essa influência tem ritmos cronológicos distintos. Quando começa a revolução portuguesa, o PCP tem uma escassa influência na Intersindical, nesta altura ainda um embrião, com apenas 12 sindicatos $^{84}$, e o PCE, por seu turno, tinha já uma grande influência nas CCOO que tinham vindo a desenvolver-se desde a década de $60^{85}$. O significado político disto é

82 Foreign Office, Central Department and Foreign and Commonwealth Office, Southern European Department: Registered Files (C and WS Series) FCO 9/2072. Visit by Dr Mario Soares, Portuguese Minister of Foreign Affairs to London and other European capitals, 1-6 May 1974. Visit by Dr Mario Soares, Portuguese Minister of Foreign Affairs to London and other European capitals, 1-6 May 1974 Foreign Office,Date: 1974.Source: The Catalogue of The National Archives.

83 Doménech SAmpere, Xavier, «El Cambio Político (1962-1976). Materiales para una perspectiva desde abajo», Historia del Presente. La sociedad Española durante el Segundo Franquismo, 1 (2002), pág. 46.

84 VALENTE, José, «O Movimento Operário e Sindical (1970-1976): entre o Corporativismo e a Unicidade», en BRITO, J.M. Brandão, O País em Revolução, Lisboa, Editorial Noticias, 2001, págs. 209-251.

85 EllwOOD, Sheelagh, «La Clase Obrera bajo el Regímen de Franco», en PRESTON, Paul, España en Crisis, México-Madrid- Buenos Aires, Fundo de Cultura Económica, 1978, págs. 265-302. 
que quando se dão as mudanças de regime, o PCE consegue ter uma influência sindical maior que o PCP, que vê as comissões de trabalhadores inúmeras vezes desrespeitarem ou enfrentarem-se com os sindicatos, afectos ao PCP, comissões fortemente influenciadas pela extrema esquerda ${ }^{86}$. Mais tarde, a partir de 1975 e sobretudo 1976, o PCP conseguirá vencer a batalha da unicidade sindical e ter uma influência esmagadora sobre a Intersindical, enquanto em Espanha o PCE, embora com influência política maioritária sobre as CCOO, é obrigado a partilhar a direcção sindical com o PSOE e também com inúmeras tendências dentro das próprias CCOO.

A questão sindical vai ser determinante na forma como ambos os partidos vão enquadrar as lutas operárias na Península Ibérica. A política do PCP e a do PCE será a de enquadrar o mais possível a tensão social dentro das estruturas reivindicativas ligadas ao aparelho sindical, por um lado, e por outro oporem-se àquilo que consideram o radicalismo da extrema-esquerda. O PCE adverte para o "perigo de radicalização» ${ }^{87}$; o comunicado do Comité Central do PCP, de 28 de Maio de 1974, escreve sobre as greves que: «Estamos perante o conluio dos elementos mais reaccionários ainda não desalojados das suas posições pelo movimento de 25 de Abril, os quais, com a ajuda consciente de grupos aventureiros ditos de esquerda, procuram empurrar a situação para o caos económico e destruir as conquistas democráticas até agora alcançadas. (...) Estas manobras, daqueles que estão interessados na contrarevolução e no retorno do fascismo, são facilitadas pela acção de grupos e grupelhos aventureiros que sob uma fraseologia de esquerda estão dando o flanco às manobras contra-revolucionárias (...). Nas condições actuais, a arma da greve deve ser cuidadosamente usada e só depois de esgotadas outras formas de luta através da negociação com o patronato e quando a resistência impeça a conquista de reivindicações realistas (...). É necessário impedir que se arrastem os conflitos sociais, que a vida económica e social seja gravemente afectada por greves, que a desorganização da produção dos transportes e dos abastecimento provoquem um amplo descontentamento (...).»88

Por contrate com a relação de animosidade com a extrema-esquerda, ambos os partidos delinearão como estratégicas as alianças que fazem com as organizações socialistas, o PSOE e o PS. O PCE formalizará essa aliança na Coordinación Democrática ou PlataJunta, que se forma em 26 de Março de

86 VAlENTE, José, «O Movimento Operário e Sindical (1970-1976): entre o Corporativismo e a Unicidade», en BRITO, J.M. Brandão, O País em Revolução, Lisboa, Editorial Noticias, 2001, págs. 209-251.

87 COHEN, Arón, «La reforma agraria de 1974-75 en Portugal y la transición española a la democracia: algunas reflexiones», en PIÇARRA, Constantino, Campos do Sul, Lisboa, IHC, 2009.

88 "Comunicado sobre as manobras da reaç̧ão», 28 de Maio de 1974, Comunicados do CC do PCP, Abril/Dezembro de 1974, Lisboa, Avante!, 1976, págs. 31-35. 
1976, resultado da fusão da Junta Democrática de Espanha (estabelecida em 1976 pelo PCE) com a Plataforma de Convergência Democrática (fundada em 1975 pelo PSOE). O PCP apostará, mesmo nos momentos mais críticos, como é o do V Governo, em reconstituir a aliança governativa com o PS.

Do ponto de vista eleitoral, os resultados dos partidos comunistas ibéricos são distintos mas não totalmente discrepantes, representando ambos os partidos uma força eleitoral entre os $10 \%$ e os $12 \%$. No dia 25 de Abril de 1975 realizaram-se em Portugal as primeiras eleições livres com sufrágio universal da história do País. 5711829 portugueses foram votar, o que corresponde a uma taxa de 91,66\% de participação, a maior da história de Portugal — e que nunca mais seria repetida. O resultado é uma extraordinária vitória do PS e um resultado confortável para o PPD: PS $(37,9 \%)$, PPD $(26,4)$, PCP $(12,5)$, CDS $(7,6)$, MDP $(4,1)$, UDP $(0,8)$. O PCP tem pouco mais de $12 \%$ dos votos. Se lhe juntarmos o MDP, isso dá cerca de 16,5\% dos votos. Em Espanha, as eleições realizam-se a 15 de Junho de 1977 e têm uma participação bastante inferior às de Portugal. Ao todo vão votar $79,4 \%$ dos eleitores. A UCD reúne $34 \%$ dos votos, o PSOE $29,2 \%$, o PCE $9,2 \%$ e a AP $8 \% 89$.

No que diz respeito à antiga «questão agrária», a dimensão da conflitualidade social imporá ao PCP que lidere a reforma agrária nos campos do Sul de uma forma mais radical que o PCE. Campos do Sul onde em média 5\% das explorações agrícolas possuíam $85 \%$ da terra ${ }^{90}$. Constantino Piçarra, investigador da reforma agrária no Alentejo, conclui no seu estudo que: 1) o PCP responde politicamente ao processo de ocupação de terras quando ele já está em curso, para dirigi-lo, mas não o inicia; 2) A reforma agrária dá-se inicialmente pela crescente noção por parte dos assalariados agrícolas de que a sua principal reivindicação — ter emprego garantido 12 meses por ano- só seria assegurada na realização de uma reforma agrária; 3) a política central do PCP vai ser uma proposta de reforma que excluiu paulatinamente ao longo do primeiro semestre de 1975 a associação livre de pequenos proprietários em cooperativas e propõe como alternativa a expropriação de terras para serem geridas por herdades do Estado, as Unidades Colectivas de Produção (UCPs).

O PCP foi o partido dominante nos campos do Alentejo e do Ribatejo. Pela sua capacidade de organização, linguagem e recrutamento classistas, predominância do proletariado rural na região, funcionários permanentes, colaboração do MFA na reforma agrária, apoio do Ministério da Agricultura e do

89 http://www.cprcalahorra.org/alfaro/Material/Historia\%20de\%20Espa\%C3\%B1a/ Documentos/Resultados\%20elecciones\%20generales\%20junio\%201977.pdf, consultado a 15 de Outubro de 2010.

90 BARreto, António, «Classe e Estado: os Sindicatos na Reforma Agrária», Análise Social, XX, 80 (1984 )- 1, págs. 45. 
Ministério do Trabalho e a implantação antiga e tradicional do PCP ${ }^{91}$. Os assalariados agrícolas são uma reserva estratégica de militância do PCP, fosse porque são o seu bastião histórico (mais de 40 anos de resistência na clandestinidade tinham aqui uma das suas forças principais), fosse porque a industrialização dos anos 60 do século XX tinha imposto a ida de muitos destes assalariados para as cinturas industriais das cidades, como proletários industriais, que aí mantinham a tradição, a ligação e a reprodução do partido.

Os documentos do PCE respeitantes à reforma agrária, incluindo o Manifesto Programa apresentado na II Conferência do PCE em 1975, não abandonam esta como um objectivo político, embora o partido vá ter um papel mais activo a este respeito com as lutas sociais da segunda metade dos anos 70, que vão desembocar em acções reivindicativas da reforma agrária, como a Marcha por la Reforma Agrária promovida pelas Comisiones Obreras del Campo, em 1983, ou as ocupações de propriedades pelo SOC, Sindicato de Obreros del Campo. Mas a prática política do PCE, de acordo com Arón Cohen, será a de não questionar a propriedade da terra ${ }^{92}$, em contraste com o que fez o PCP.

No que diz respeito à política externa, os partidos também aqui adaptarse-ão à realidade nacional, sem pôr em causa a política da «coexistência pacífica», que em 1975 é selada em Helsínquia. Quando surge a discussão do papel de Portugal na NATO (OTAN, Organização do Tratado do Atlântico Norte), depois do 25 de Abril de 1974, o PCP muda a sua posição face ao Programa anterior do partido, publicado sob o título Rumo à Vitória93, e passa a ser a favor do «respeito pelos compromissos internacionais decorrentes dos tratados em vigor» ${ }^{94}$, que estava previsto no programa do MFA, e essa é a posição que irá defender, no Governo e fora dele. O PCP ambiciona uma NATO menos hegemonizada pelos Estados Unidos e considera que a segurança de Portugal depende da segurança colectiva à escala da Europa, mas sem pôr em causa a NATO ${ }^{95}$. Ainda no campo da política externa é definido como prioritário pelo PCP o estabelecimento de relações diplomáticas entre a URSS e Portugal, visto como um factor «relevante» na democratização de Portugal, para a segurança da Europa, na base dos «princípios da coexistência pacífica» ${ }^{96}$. Em Agosto de 1974, quando está a decorrer a Conferência para a

91 Ibidem.

92 CoHEN, Arón, «La reforma agraria de 1974-75 en Portugal y la transición española a la democracia: algunas reflexiones», en PIÇARRA, Constantino, Campos do Sul, Lisboa, IHC, 2009.

93 Cunhal, Álvaro, Rumo à Vitória. As Tarefas do Partido na Revolução Democrática e Nacional, Lisboa, Edições Avante!, 2001.

94 «Portugal e a OTAN», Avante!, Série VII, 20 de Junho de 1974, pág. 4.

95 Ibidem.

96 «Nota sobre o estabelecimento de relações diplomáticas com a URSS», 10 de Junho de 1974, Comunicados do CC do PCP, Lisboa, Edições Avante!, 1975’ págs. 41-44. 
Segurança e Cooperação na Europa, o PCP vem a público defender o programa do XXIV Congresso do PCUS, onde é aprovada a política externa conhecida como o Programa de Paz, que na conclusão afirma que um dos «problemas básicos do desanuviamento e da consolidação da paz mundial é a garantia de segurança europeia com base no reconhecimento da realidade territorial e política derivada da segunda guerra mundial» ${ }^{97}$. A Espanha, por seu turno, estava fora da NATO e o PCE continuará a participar em manifestações, até à década de 1980, contra o ingresso de Espanha na Aliança Atlântica. Também para o PCE a política da coexistência pacífica é inquestionável. No que diz respeito à adesão à CEE, o PCE defende-a desde cedo ${ }^{98}$ e o PCP é contra e assim se manterá até à década de 80 do século XX.

Não é claro que o PCP tenha tido relações de animosidade com todos os partidos eurocomunistas. A nossa investigação leva-nos a concluir que é sobretudo com o PCE que, por vezes, as relações se tornam tensas, mas o mesmo não se passa com as relações entre o PCP, o PCF e o PCI, que se mantêm sempre num quadro de grande cordialidade e cooperação.

Os dois mais importantes partidos comunistas da esfera eurocomunista, o francês e o italiano, enviam delegações a Portugal justamente em Novembro de 1974, altura também em que o PCP comemora o aniversário da revolução de Outubro, a 7 de Novembro de 1974. Se PCP e PCE trocarão algumas palavras amargas no Verão de 1975, e só a partir do processo de radicalização em Portugal porque antes as relações são cordiais $^{99}$, isso nunca acontecerá entre os comunistas portugueses, o PCF e o PCI.

A chegada da delegação do PCF, chefiada pelo seu secretário-geral, é amplamente divulgada por todos os meios do partido. Realizam-se reuniões do CC com o CC do PCF e é feito um comício de amizade entre os dois partidos no Pavilhão dos Desportos, na segunda semana de Novembro de 1974. Georges Marchais, no seu discurso, saúda o fim da ditadura, o aprofundamento da democracia, a política de coexistência pacífica e a derrota da «reacção». Defende que em Portugal e em França vive-se uma etapa de democracia «avançada», que "pressupõe um grande impulso nacional» ${ }^{100}$ que levará à derrota do capitalismo. Cunhal discursa também agradecendo a Marchais a solidariedade do PCF e salienta que «a situação objectiva precisa de unidade» e que se deve «derrotar a conspiração no ovo» ${ }^{101}$.

97 Avante!, Série VII, 30 de Agosto de 1974.

98 Preston, Paul, España en Crisis, México-Madrid-Buenos Aires, Fundo de Cultura Económica, 1978, pág. 257.

99 Mundo Obrero, 4 de Junio de 1974, pág. 1. pág. 7.

100 «O Discurso de Georges Marchais», Avante!, Série VII, 15 de Novembro de 1974, 101 «O Discurso de Álvaro Cunhal», Avante!, Série VII, 15 de Novembro de 1974, pág. 7. 
O encontro entre PCP e PCF resulta num comunicado conjunto, bilingue, dos dois partidos, feito a 14 de Novembro de 1974. Nele pode ler-se que a reunião entre Georges Marchais, Guy Hermler (membro do Bureau Político do PCF) e Roger Trugnan (Política Externa do Comité Central do PCF) e Álvaro Cunhal, Sérgio Vilarigues, Joaquim Pires Jorge e Aurélio Santos (todos membros do Comité Central do PCP) decorreu em clima de «calorosa amizade» e coincidência sobre «todas as questões examinadas». O PCP informou do derrube do fascismo, da importância do MFA, da unidade das forças democráticas e da importância da independência das colónias. Saúda o povo francês na luta pelas reformas democráticas. O PCF expressa solidariedade ao MFA e ao PCP pelo derrube do fascismo e afirma defender os direitos dos trabalhadores portugueses imigrados em França. Os dois partidos apoiam a independência da Guiné e a lutas dos povos de Moçambique e Angola. Apoiam o «desanuviamento» e a conclusão rápida da Conferência para a Segurança e Cooperação Europeia. Os dois partidos, na base do marxismoleninismo e do internacionalismo proletário, afirmam querer contribuir para o movimento operário internacional. ${ }^{102}$ Também Ugo Pechiolli, chefe da delegação do PCI, estará em Portugal no fim de Novembro de 1974, onde cauciona a política do PCP. No seu discurso afirma: «Percebemos perfeitamente que estais numa fase de construção do regime democrático e que os nossos inimigos ainda têm muita força.»103.

A primeira vez que Santiago Carrillo visita Portugal depois da Revolução dos Cravos é em Dezembro de 1974, a convite de Mário Soares, líder do PS. Carrillo também se encontra com a comissão política do PCP, mas privilegia, no quadro já da estratégia eurocomunista (assumida em Livorno em 1975 e depois teorizada em Eurocomunismo e Estado ${ }^{104}$ ) a cooperação com o PS. A relação entre Santiago Carrillo e Álvaro Cunhal esfria depois de Março de 1975 e sobretudo depois da formação do V Governo. Tal crispação deve, de acordo com os dados de que dispomos hoje, ser compreendida num marco das situações históricas concretas de cada país e não à luz de rupturas estratégicas entre ambos os partidos. O sinal que Carrillo tem a dar a Espanha é o da aliança com a «direita civilizada» e as críticas públicas a Álvaro Cunhal ${ }^{105}$ são um sinal preciso à direita espanhola e ao PSOE da sua ruptura com Moscovo e do seu empenhamento numa solução negociada na transição. Mas ver nestas diferenças um PCE democrático e um PCP revolucionário é ignorar o

102 Um Mesmo Combate. PCP e PCF, Lisboa, Edições Avante!, 1974, pág. 51.

103 «Portugal saberá consolidar a Grande Vitória do 25 de Abril», Avante!, 2 Série VII, 2 de Novembro de 1974, pág. 5.

${ }^{104}$ CARrillo, Santiago, O «Eurocomunismo» e o Estado, Lisboa, Presença, 1977.

105 SANChez Cervelló, J., A Revolução Portuguesa e a sua Influência na Transição Espanhola, Lisboa, Assírio e Alvim, 1993, pág. 382. 
ritmo, diferente, da conflitualidade social em Portugal e Espanha. Aliás, se assim não fosse não se explicaria porque é que Santiago Carrillo apela sistematicamente nas páginas do Mundo Obrero à greve geral e o PCP nunca o faz, em 19 meses de processo revolucionário em Portugal. Só o compreendemos se tivermos em conta que Álvaro Cunhal estava no Governo e Santiago Carrillo pertencia a um partido ilegal.

Estrategicamente, ambos os partidos alinhavam com a politica da «coexistência pacifica» e estavam empenhados em assegurar a democratização de Portugal e Espanha, a estabilidade interna dos seus países, refazer as alianças, findas as mais longas ditaduras europeias do pós-guerra. Defendendo aquilo que os seus programas, quer o do PCP ${ }^{106}$, quer o do $\mathrm{PCE}^{107}$, estabeleciam como uma «aliança anti-latinfundista e anti-monopolista» que devia pôr fim à oligarquia que governava o país, através de uma aliança com os sectores progressistas das elites nacionais. Ambos os partidos viviam o fantasma do Chile, isto é, um golpe de direita que repusesse a ditadura e pusesse fim à unidade de tipo frente popular que se estava a criar institucionalmente (em Portugal) ou de facto, com os acordos que vieram a saldar-se no pacto de aceitação da monarquia e um regime económico de feição liberal (em Espanha). O PCP organiza várias acções de apoio solidário ao Chile: «em qualquer parte do mundo onde os trabalhadores, os povos se ergam contra o fascismo, estão lutando não somente pela libertação como também dando passos na conquista de democracia a nível internacional» ${ }^{108}$. Encarnación Lemus concluiu que a transição espanhola situou-se, entre outros factores, entre o medo da revolução portuguesa e a experiência do golpe chileno. O mesmo Chile que depois irá beber a experiência da transição espanhola nos anos $80^{109}$.

Os dois partidos jogaram um papel importante na contenção de uma situação de conflitualidade que poderia desembocar numa guerra civil ${ }^{110}$, mesmo que para isso tivessem de aceitar o regime capitalista e as regras da economia de mercado. As economias não ficaram, porém, com um grau de intervenção estatal idêntica - os Pactos da Moncloa, assinados no final de 1977, são mais liberalizantes do que a situação económica que resulta do 25

106 «Política Clara e Transparente», In Avante!, Série VII, 23 de Janeiro de 1975, pág. 2.

107 COHEN, Arón, «La reforma agraria de 1974-75 en Portugal y la transición española a la democracia: algunas reflexiones», en PIÇARRA, Constantino, Campos do Sul, Lisboa, IHC, 2009, pág. 26.

108 «Portugal Libertado não Esquece o Chile Oprimido», Avante!, Série VII, 6 de Setembro de 1974, pág. 1.

${ }^{109}$ LEMUS, Encarnación, En Hamelin...La Transición Española más allá de la Frontera, Oviedo, Septem Ediciones, 2001, pág. 117.

110 Preston, Paul, «La crisis del franquismo (1969-1977)», en TUÑON DE LARA, Manuel y Fusi, Juan Pablo et al., História de España, Madrid, História 16, 1986; RosAs, Fernando, Pensamento e Acção Política. Portugal Século XX (1890-1976), Lisboa, Editorial Notícias, 2004. 
de Novembro de 1975 em Portugal, que mantém, por cerca de dez anos, um importante sector dos bancos e empresas nacionalizados. PCP e PCE procuraram obter, no quadro do regime capitalista, e com variações consoante a negociação levada a cabo com os outros partidos, o máximo de mecanismos de regulação das economias nacionais, intervenção por parte do Estado, benefícios sociais e direitos laborais para os trabalhadores, sem contudo romper com o modo de produção e aceitando um pacto social que assentou na negociação tripartida entre sindicatos, patrões e Estado.

Fecha de recepción: 22-02-2011

Fecha de aceptación: 4-04-2012 